19 Revue d'histoire du XIXe siècle

Société d'histoire de la révolution de 1848 et des

révolutions du XIXe siècle

$4 \mid 1988$

Varia

\title{
Victor Schœlcher, mythe et réalité
}

\section{Nelly Schmidt}

URL: http://journals.openedition.org/rh19/26

DOI: $10.4000 /$ rh19.26

ISSN: $1777-5329$

\section{Publisher}

La Société de 1848

\section{Printed version}

Date of publication: 1 June 1988

ISSN: 1265-1354

\section{Electronic reference}

Nelly Schmidt, «Victor Schœlcher, mythe et réalité », Revue d'histoire du XIXe siècle [Online], 4 | 1988 Online since 09 September 2008, connection on 01 May 2019. URL : http://journals.openedition.org/ rh19/26 ; DOl : 10.4000/rh19.26

This text was automatically generated on 1 May 2019.

Tous droits réservés 


\section{Victor Schœlcher, mythe et réalité}

Nelly Schmidt

\section{ABSTRACTS}

No abstract available by now

Pas de résumé disponible actuellement

INDEX

Mots-clés: Schœlcher Victor, Esclavage 